\title{
UNJUK KERJA TURBIN AIR TIPE CROSS FLOW DENGAN VARIASI DEBIT AIR DAN SUDUT SERANG NOSEL
}

\author{
Yudi Setiawan, Irfan Wahyudi, Erwin Nandes \\ Jurusan Teknik Mesin, Universitas Bangka Belitung \\ Jl.Merdeka no. 04 Pangkalpinang \\ E-mail : yudiubb@yahoo.co.id
}

\begin{abstract}
Abstrak
Turbin air adalah suatu mesin yang menghasilkan energi mekanik berupa putaran poros dengan memanfaatkan energi potensial air. Energi ini selanjutnya diubah menjadi bentuk energi lain seperti energi listrik. Turbin air yang digunakan di Indonesia sebagian besar adalah turbin aliran silang (cross flow). Turbin cross flow memiliki kontruksi yang sederhana dan memberikan biaya operasional kecil. Pentingnya dilakukan penelitian ini adalah untuk mengetahui pengaruh debit air dan variasi sudut serang nosel terhadap unjuk kerja turbin cross flow. Penelitian ini dilakukan menggunakan instalasi penelitian yang tersusun atas beberapa peralatan utama. Diantaranya runner (piringan dan sudu), nosel, rotameter, tachometer, dan neraca pegas. Penelitian ini menggunakan debit $5 \mathrm{gpm}$ dan $10 \mathrm{gpm}$ dengan variasi sudut serang nosel mulai dari $10^{\circ}, 20^{\circ}, 30^{\circ}$, $40^{\circ}, 50^{\circ}, 60^{\circ}, 70^{\circ}$, dan $80^{\circ}$ menggunakan sudu berjumlah 18 . Unjuk kerja turbin cross flow ditunjukkan berdasarkan daya, putaran dan efisiensi turbin yang dihasilkan dari percobaan. Hasil percobaan menunjukkan bahwa debit 10 gpm ternyata lebih baik dibandingkan debit 5 gpm yaitu pada putaran $(131,7 \mathrm{rpm})$, daya $(0,901$ watt) dan efisiensi $(72,90 \%)$ terjadi pada sudut $30^{\circ}$.
\end{abstract}

Kata kunci : Debit, Sudut Serang Nosel, Daya Turbin, Putaran, Efisiensi.

\section{PENDAHULUAN}

Sumber migas yang terdapat di bumi sangat terbatas dan pada suatu saat akan habis. Saat ini energi listrik merupakan salah satu sumber energi vital bagi kehidupan manusia, baik sektor rumah tangga, komersial, publik maupun industri. Havinato, J. (2009) menyatakan turbin cross-flow merupakan jenis turbin yang dikembangkan oleh Anthony Michell (Australia), Donat Banki (Hongaria) dan Fritz Ossberger (Jerman). Turbin crossflow dapat dioperasikan pada debit 20 litres/sec hingga $10 \mathrm{~m}^{3} / \mathrm{sec}$ dan head antara $1 \mathrm{~s} / \mathrm{d} 200 \mathrm{~m}$. Beberapa keunggulan turbin cross flow diantara kisaran operasi yang luas, sebagai alternatif Turbin Francis, pengaturan efisiensi yang tetap tinggi pada debit rendah, mudah dan murah proses fabrikasi dan pemeliharaan. Namun juga memiliki keterbatasan yaitu efisiensi lebih rendah dan pengaturan secara load control.

Beberapa penelitian tentang turbin air antara lain, Salim (2009) melakukan uji kelayakan turbin cross flow menggunakan pipa 3 inchi dan jumlah sudu 10 buah menghasilkan efisiensi dan daya terbesar juga pada sudut 30 pada debit $10 \mathrm{gpm}$ dibandingkan debit $6 \mathrm{gpm}$ dan 8 gpm sebesar 3,96\%. Hasil ini memang lebih kecil dibandingkan penelitian yang dilakukan menghasilkan efisiensi mesin turbin sebesar 14,56 \%. Winardi, dkk (2004) menyimpulkan bahwa semakin banyak jumlah sudu, putaran turbin semakin meningkat. Sedangkan Setyarini, P., dkk, (2012) bahwa pada posisi sudut pancar miring torsi, daya dan efisiensi turbin air aliran silang lebih tinggi dibandingkan pada posisi sudut pancar horizontal atau vertikal.

Sumber energi ini berupa air sungai di wilayah pemukiman daerah perbukitan, ada beberapa air sungai yang dapat dimanfaatkan untuk membangkitkan energi listrik dengan menggunakan turbin air untuk memenuhi kebutuhan energi penduduk di sekitarnya. Turbin air tipe cross flow paling banyak diaplikasikan di masyarakat sebagai sebuah bagian dari pembangkit listrik tenaga air skala kecil (mikrohidro). Penelitian ini bertujuan untuk mengetahui pengaruh variasi sudut serang dan debir air terhadap unjuk kerja (putaran, daya dan effisiensi) turbin air tipe cross flow.

\section{METODE PENELITIAN}

Peralatan penelitian dirangkai dalam suatu instalasi penelitian yang tersusun atas pompa sentrifugal dengan spesifikasi debit maksimal $340 \mathrm{~L} / \mathrm{m}$ yang tersusun atas beberapa 


\section{Yudi Setiawan, Irfan Wahyudi, Erwin Nandes}

peralatan utama. Diantaranya runner (piringan dan sudu), nosel, rotameter, tachometer, dan neraca pegas. Penelitian ini menggunakan debit $5 \mathrm{gpm}$ dan $10 \mathrm{gpm}$ dengan variasi sudut serang nosel mulai dari $10^{\circ}, 20^{\circ}, 30^{\circ}, 40^{\circ}, 50^{\circ}, 60^{\circ}, 70^{\circ}$, dan $80^{\circ}$ menggunakan sudu berjumlah 18 .

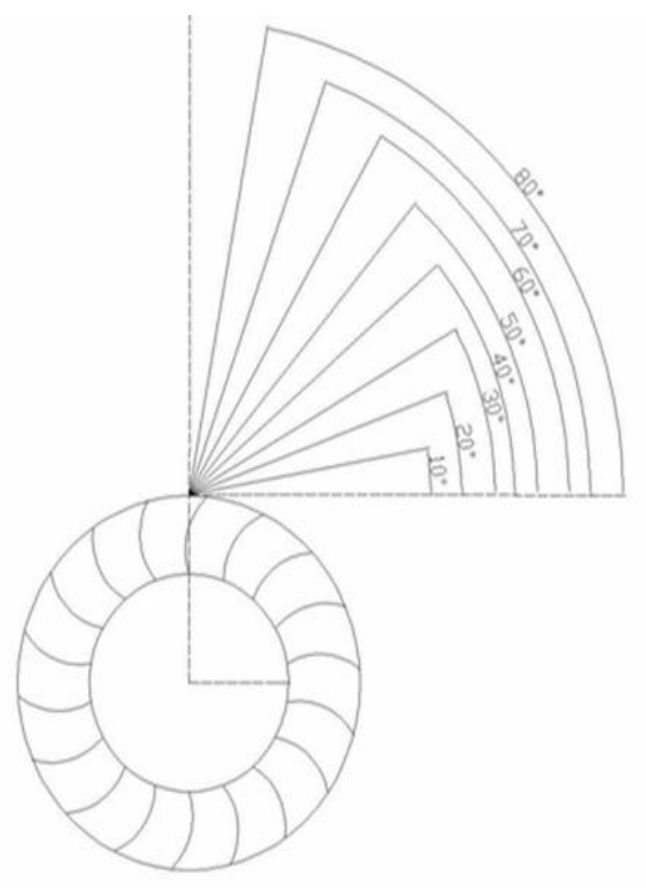

(a)

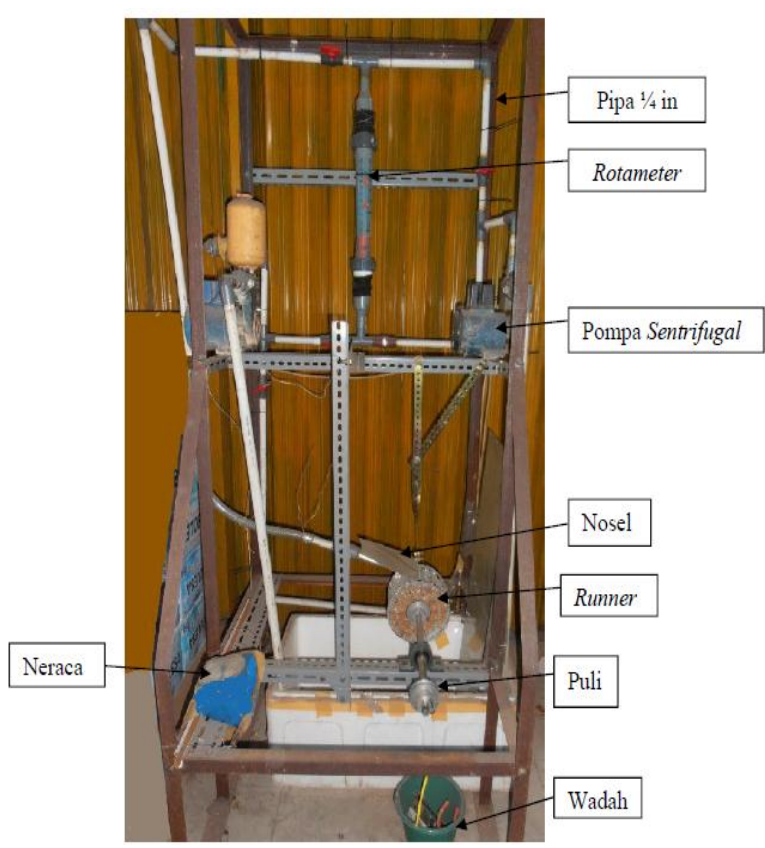

(b)

Gambar 1.(a) variasi sudut serang nosel (b) Instalasi Penelitian
Unjuk kerja turbin cross flow ditunjukkan berdasarkan daya $(\mathrm{P})$, putaran $(\mathrm{N})$ dan efisiensi turbin $(\mu)$. Daya teoritis (po) adalah daya yang mungkin dihasilkan oleh potensi air yang ada. Daya turbin $\left(\mathrm{P}_{\mathrm{T}}\right)$ adalah daya yang dihasilkan setelah daya teoritis tersebut dikonversi oleh turbin menjadi daya mekanik. Dietzel, Fritz (1990), besarnya daya teoritis:

$$
p o=\frac{1}{2}(\rho Q) v^{2} \text { dimana } V^{2}=\sqrt{ } 2 g h
$$

Turbin air cross flow yang sedang dialiri air dengan debit (Q) akan berputar dengan kecepatan putaran turbin $(\mathrm{N}) \mathrm{rpm}$. Untuk setiap nilai $\mathrm{Q}$ yang dipilih, dilakukan pembebanan pada poros turbin hingga putaran turbin mencapai $0 \mathrm{rpm}$. Besarnya beban $(M)$, dapat digunakan untuk mengetahui besarnya torsi turbin $(T)$ yang pada akhirnya didapatkan daya turbin.

$$
\text { Daya turbin } \quad P_{T}=T \cdot \frac{2 \pi N}{60}
$$

Nilai torsi (T) didapat dari selisih tegangan tali dengan beban kemudian dikalikan dengan jari-jari puli (R). Rumus untuk menghitung torsi adalah sebagai berikut :

$$
T=(W-F) \cdot R
$$

Dari persamaan diatas dapat diperoleh rumus effisiensi turbin $\left(\mathrm{y}_{T}\right)$ sebagai berikut:

$$
\text { Efisiensi turbin } \quad \mathrm{y}_{T}=\frac{P_{O}}{P_{T}}
$$

HASIL DAN PEMBAHASAN

Variasi Perubahan Sudut Serang Terhadap Putaran Maksimum Turbin

Tabel 1. Pengaruh Perubahan sudut serang terhadap putaran maksimum turbin

\begin{tabular}{|c|c|c|}
\hline \multirow{2}{*}{ Sudut } & \multicolumn{2}{|c|}{ Putaran Turbin (rpm) } \\
\cline { 2 - 3 } Serang & Q = 5 gpm & Q = 10 gpm \\
\hline 10 & 117,367 & 145,233 \\
\hline 20 & 132,033 & 193,267 \\
\hline 30 & 134,9 & 200,5 \\
\hline 40 & 124,9 & 175 \\
\hline 50 & 67,0667 & 102,533 \\
\hline 60 & 46,9 & 99,4667 \\
\hline 70 & 0 & 38,8667 \\
\hline 80 & 0 & 0 \\
\hline
\end{tabular}




\section{Yudi Setiawan, Irfan Wahyudi, Erwin Nandes}

Berdasarkan tabel 1 perubahan sudut serang nozel terhadap kecepatan putaran turbin sangat berpengaruh. Kisaran besar putaran turbin pada debit 5 gpm yaitu $0-140 \mathrm{rpm}$. Pada debit air $(\mathrm{Q})=5 \mathrm{gpm}$ ternyata sudut $30^{\circ}$ memiliki kecepatan putaran turbin paling tinggi yaitu 134, 9 rpm. Sedangkan pada sudut serang yang lainnya putaran turbin semakin menurun. Bahkan pada sudut $70^{\circ}$ dan $80^{\circ}$ tidak dihasilkan putaran sama sekali. Hal ini berhubungan dengan posisi sudut yang semakin horizontal pada sudut kecil dan semakin vertikal pada sudut yang semakin besar. Sehingga posisi jatuhnya air terhadap turbin tidak maksimum untuk sudut yang cenderung horizontal maupun vertikal. Sebab pada posisi miring merupakan posisi terbaik dibandingkan dengan posisi horizontal atau vertikal (Soenoko, R. 1992).

Secara umum perbedaan putaran turbin terhadap perubahan sudut serang dapat dilihat pada gambar 2 berikut.

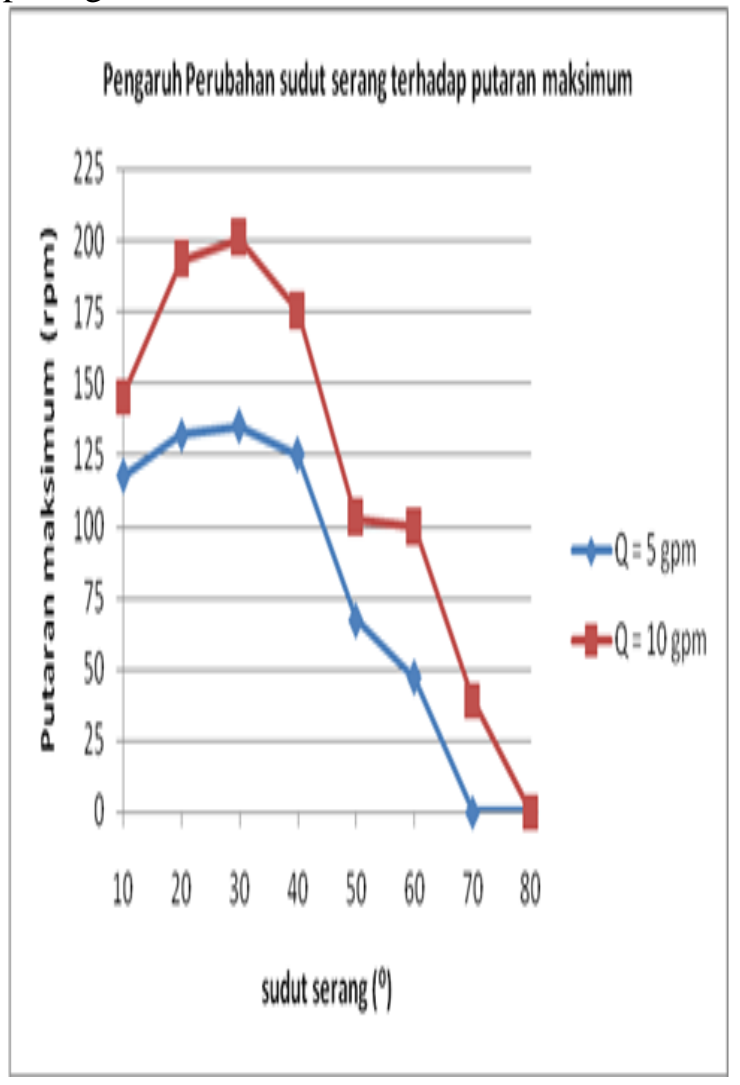

Gambar 2 Grafik Perubahan Sudut Terhadap Putaran Turbin

Kisaran besar putaran turbin pada debit $5 \mathrm{gpm}$ yaitu $0-201 \mathrm{rpm}$. Sama halnya pada debit air $(\mathrm{Q})=10 \mathrm{gpm}$, sudut $30^{\circ}$ memiliki pengaruh terbesar untuk kecepatan turbin yaitu dihasilkan 200,5 rpm. Hanya saja pada sudut $70^{\circ}$ untuk debit air sebanyak $10 \mathrm{rpm}$ masih dihasilkan putaran turbin meskipun jumlah kecil.

Hal ini terjadi karena memang sudut terbaik untuk mendapatkan daya dan efisiensi maksimum pada suatu turbin air cross flow dilakukan pada sudut $30^{\circ}$. Dikarenakan pada sudut ini memang kecepatan air terbesar terjadi akibat pengaruh posisi semburan yang miring. Sebab pada posisi miring merupakan posisi terbaik dibandingkan dengan posisi horizontal atau vertikal ( Soenoko, R. 1992).

\section{Hubungan Putaran Turbin Pada Daya Maksimum untuk $Q=5 \mathrm{gpm}$}

Perbedaan daya maksimum yang dihasilkan pada setiap putaran turbin untuk sudut serang yang berbeda dapat dilihat pada gambar 3 berikut:
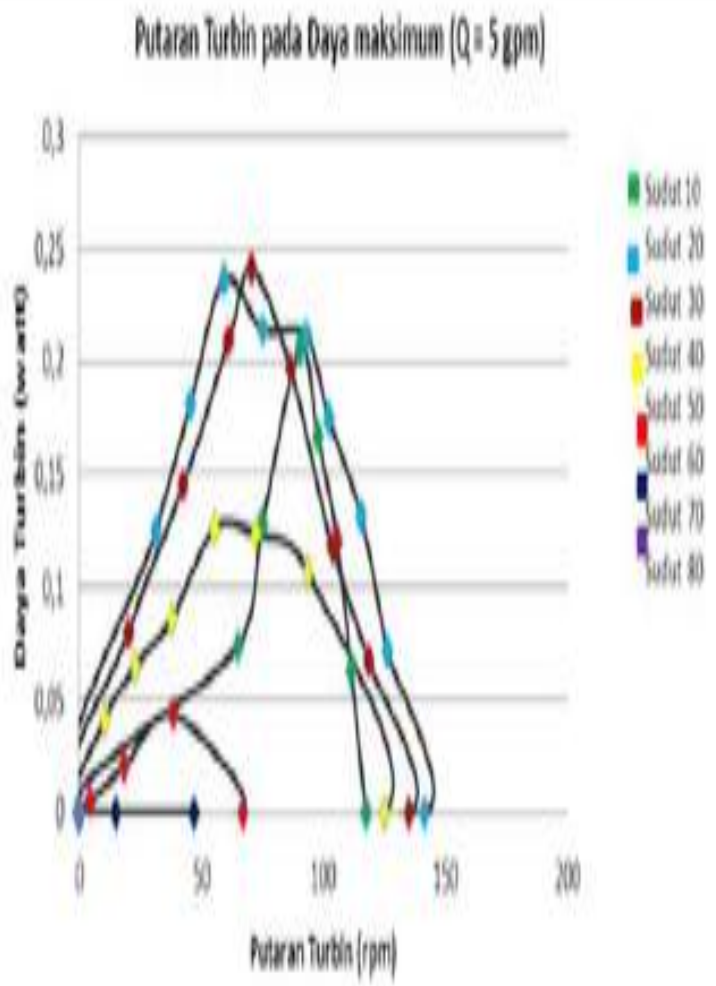

Gambar 3 Grafik Daya Turbin dengan Putaran Turbin pada debit $5 \mathrm{gpm}$

Daya terbesar dihasilkan pada saat posisi sudut serang sebesar $30^{\circ}$ yaitu daya maksimum mencapai 0,2415 watt dengan putaran turbin sebesar 70,567 rpm. Selanjutnya semakin besar sudut ternyata daya turbin mencapai titik nol (turbin tidak bergerak sama sekali). Hal ini berhubungan dengan posisi sudut serang air semakin tegak lurus turbin sehingga turbin tidak bergerak. 


\section{Hubungan Putaran Turbin Pada Daya Maksimum untuk $Q=10 \mathrm{gpm}$}

Pada gambar 4 terlihat perbedaan daya maksimum yang dihasilkan pada setiap putaran turbin untuk sudut serang yang berbeda.

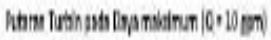

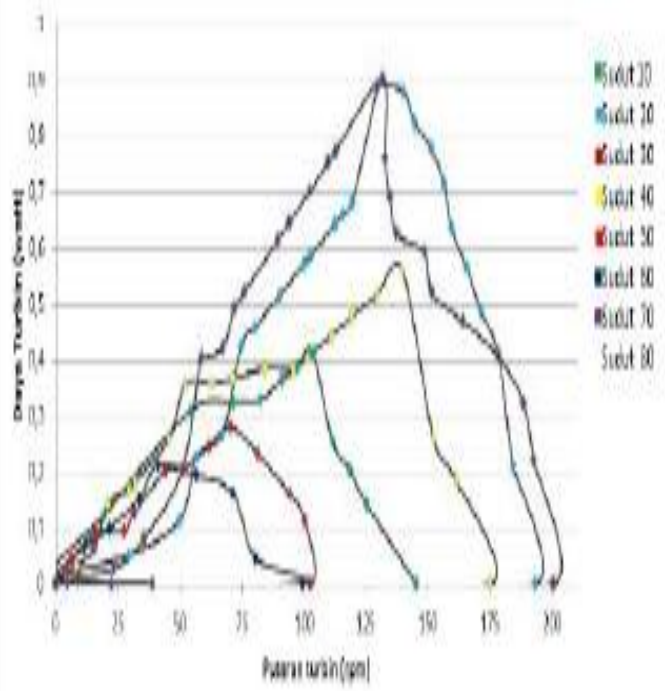

Gambar 4 Grafik Daya Turbin dengan Putaran Turbin pada debit 10 gpm

Daya terbesar dihasilkan pada saat posisi sudut serang sebesar $30^{\circ}$ yaitu daya maksimum mencapai 0,901 watt dengan putaran turbin sebesar 131,7 rpm. Selanjutnya semakin besar sudut ternyata daya turbin semakin kecil hingga mencapai titik nol (turbin tidak bergerak sama sekali). Namun berbeda pada percobaan debit air $5 \mathrm{gpm}$, pada debit air $10 \mathrm{gpm}$ untuk sudut $60^{\circ}$ dan $70^{\circ}$ masih dihasilkan putaran dengan daya yang semakin kecil. Hal ini disebabkan pada debit 10 gpm kuantitas/jumlah air yang masuk pada alat lebih besar sehingga memungkinkan untuk menggerakan turbin meskipun putarannya semakin kecil. Hal ini juga berhubungan dengan posisi sudut serang air semakin tegak lurus turbin sehingga putaran turbin semakin kecil hingga turbin tidak bergerak.

\section{Hubungan Putaran Turbin Pada Efisiensi Maksimum untuk $Q=5$ gpm}

Perbedaan besar efisiensi turbin pada setiap sudut serang dapat dilihat pada gambar 5 berikut:

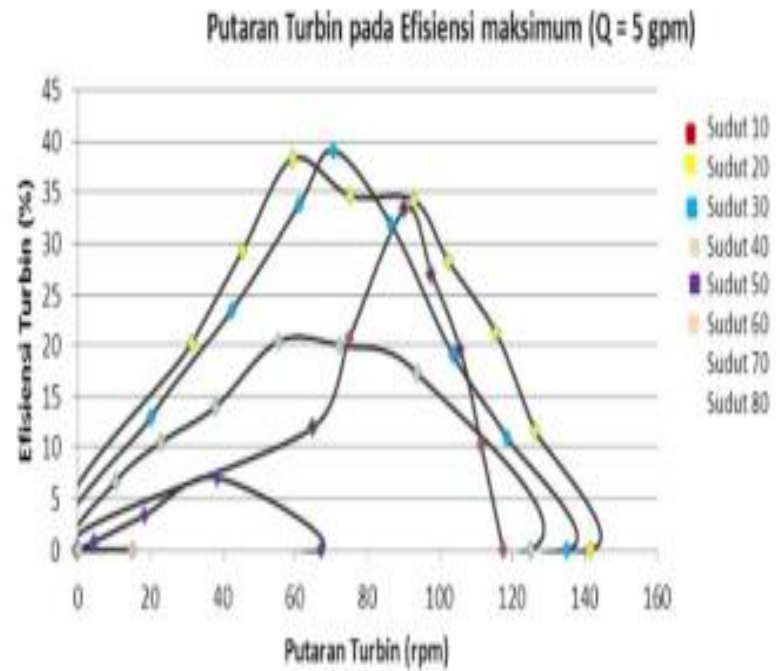

Gambar 5 Grafik Efisiensi Turbin dengan Putaran Turbin pada debit $5 \mathrm{gpm}$

Gambar 5 menjelaskan perbedaan besar efisiensi turbin pada setiap sudut serang yang diujikan. Kisaran tingkat efisiensi maksimum pada masing-masing sudut serang yaitu $0-40 \%$. Sebanding dengan besar daya turbin efisiensi turbin juga dihasilkan pada debit $5 \mathrm{gpm}$ dan sudut $30^{\circ}$ yaitu sebesar 39,07 $\%$ dengan putaran turbin 70,567 rpm.

\section{Hubungan Putaran Turbin Pada Efisiensi Maksimum untuk $Q=10$ gpm}

Hubungan antara efisiensi turbin dengan putaran turbin pada debit $10 \mathrm{gpm}$ dapat dilihat pada gambar 6 berikut:

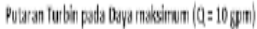

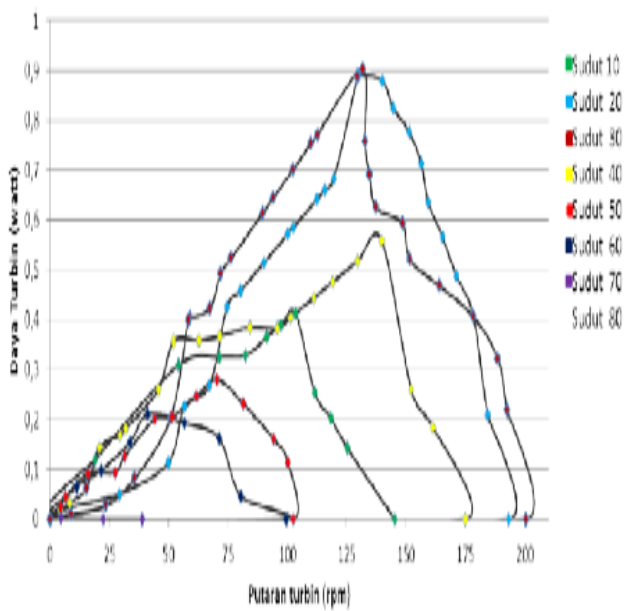

Gambar 6 Grafik Efisiensi Turbin dengan Putaran Turbin pada debit 10 gpm 
Gambar 6 menggambarkan kisaran tingkat efisiensi maksimum pada masingmasing sudut serang untuk $\mathrm{Q}=10 \mathrm{gpm}$ yaitu 0 - 75\%. Efisiensi maksimum turbin juga dihasilkan pada debit 10 gpm dan sudut $30^{\circ}$ sebesar 72,90\% dengan putaran turbin 131,7 rpm.

\section{KESIMPULAN}

Daya maksimum dan efisiensi maksimum yang dihasilkan berturut-turut adalah 0,91 watt dengan tingkat efisiensi sebesar 72,90 \% dengan kecepatan turbin sebesar 131,7 rpm terjadi pada debit $10 \mathrm{gpm}$. Sudut serang nosel terbaik untuk menghasilkan daya dan efisiensi mesin turbin air tipe cross flow adalah pada sudut $30^{\circ}$ berlaku untuk tiap debit air yang diujikan. Putaran turbin maksimum terjadi pada debit $10 \mathrm{gpm}$ dengan perbandingan debit yang diujikan $5 \mathrm{gpm}$. Semakin besar debit air yang digunakan maka semakin besar pula puataran turbin yang dihasilkan.

\section{DAFTAR PUSTAKA}

1. Dietzel, Fritz. 1990. Turbin, Pompa dan Kompresor. Jakarta : Erlangga.

2. Havinato, J. 2009. Penggunaan Turbin Cross Flow pada Pembangkit Listrik Tenaga Mikro Hidro. Deputi Manager Evaluasi Diklat dan Assessment PLN Pusdiklat.

3. Salim, N. 2009. Unjuk Kerja Turbin Air Tipe Cross flow dengan Variasi Jari-jari Kelengkungan Sudu. Yogyakarta Fakultas Teknik Universitas Gadjah Mada.

4. Setyarini, P., dkk. 2012. Unjuk Kerja Turbin Arus Lintang Berlorong Pengarah Dengan Variasi Sudut Pipa Pancar.

5. Soenoko, R. 1992. Desain Turbin Arus Lintang di Indonesia. Jurnal Vol. 1 No. 2 Desember 1992. Fakultas Teknik UNIBRAW.

6. Winardi, dkk. 2004. Pengaruh Jumlah Sudu Roda Jalan Terhadap Unjuk Kerja Turbin Aliran Silang. Jurnal Teknosains Vol. 2 No. 17 Tahun 2004. Fakultas Teknik Universitas Gajah Mada. 